\title{
The Effect of Learning Approaches and Student Learning Styles on Mathematical Reasoning Abilities
}

\author{
Rivo Panji Yudha* \\ 1 FKIP Universitas 17 Agustus 1945 Cirebon, 45131, Indonesia
}

${ }^{*}$ Corresponding author: J1. Pegajahan Desa Mandalangan RT 009 RW 002 Kelurahan Kasepuhan, Cirebon, West Java, 45131, Indonesia. email addresses: rivoyudha@yahoo.co.id

\begin{tabular}{l}
\hline a r t i c l e $\mathbf{i}$ f o \\
\hline How to cite this article: \\
Yudha, R.P. (2019). The Effect of Learning \\
Approaches and Student Learning Styles on \\
Mathematical Reasoning Abilities. Eduma: \\
Mathematics Education Learning and \\
Teaching, 8(2), 10-17 \\
doi:http://dx.doi.org/10.24235/eduma.v8i2.5344
\end{tabular}

Article history:

Received: 10 24, 2019

Accepted: 12 02, 2019

Published: 12 05, 2019

Copyright $(9) 2019$ by author (s) and EduMa: Mathematics Education Learning and Teaching under the Creative Commons Attribution-ShareAlike 4.0 International License.

\section{a b s t r a c t}

The Effect of Learning Approaches and Student Learning Styles on Mathematical Reasoning Abilities. This study aims to determine the effect of learning approaches and learning styles on students' mathematical reasoning abilities. This research was a quasiexperimental research with a $2 \times 2$ factorial design which was conducted at the Wahidin Vocational School in Cirebom City involving a sample of 70 students from a population of 335 students of class X. Sampling was done by random sampling technique. The research instrument used in the form of tests of mathematical reasoning ability and learning style questionnaire. The collected data were analyzed using the two-way Anava test. Before the twoway anava test is tested, the analysis requirements test is the normality test and the variance homogeneity test. The results of this study are: (1) there is a difference in the effect of the RME learning approach and science on students' mathematical reasoning abilities; (2) There are differences in the influence of kinesthetic learning styles, and visual on students' mathematical reasoning abilities; (3) There is no interaction between learning approaches and learning styles.

\section{Key word s :}

Learning approaches; Learning Style; Mathematical Reasoning Ability. 


\section{INTRODUCTION}

Through mathematics learning, students' thinking is expected to develop well because mathematics has a strong and clear structure and connection between concepts. Thus, mathematics is very possible to be able to improve the ability of reasoning. According to The National Council of Teachers of Mathematics (2009) that, reasoning is an inseparable part of mathematics. Students at the secondary school level must be of the view that mathematics involves checking patterns and noting regularities, making guesses about possible generalizations, and evaluating guesses.

Until now the role of the teacher in building students' mathematical reasoning abilities, especially in learning mathematics is still very limited. The task and role of the teacher is no longer as a provider of information (transfer of knowledge), but as a stimulus for students to learn (stimulation of learning) in order to construct their own knowledge Mathematical material and mathematical reasoning are two inseparable things namely mathematical material understood through reasoning and reasoning dipahami dan dilatih melalui belajar materi matematika.

Mathematical Reasoning according to Webster (Gunhan, 2014) is the ability to think coherently and logically in drawing conclusions or conclusions from facts that are known or assumed. Rizky (2017) states that reasoning is an act or thought process to infer something. Mathematics means the knowledge gained from reasoning and is the science of logical reasoning and problems related to numbers. Reasoning or the ability to think through logical ideas is the basis of mathematics. Thus, mathematical reasoning is an activity or process of drawing conclusions that are marked by the steps of the thought process.

Whereas mathematical reasoning ability according to Tipps, Johnson, \& Kennedy (2008) allows students to (a) recognize reasoning and proof as basic aspects of mathematics; (b) make and investigate mathematical allegations; (c) developing and evaluating mathematical arguments and proofs; (d) choose and use various types of reasoning and verification methods. In this research mathematical reasoning abilities include: (1) solving problems in finding patterns; (2) making generalizations; (3) evaluating mathematical arguments.

Various methods are used to improve mathematical reasoning abilities, one of which is in the learning process. Learning will not take place if there are no teachers as instructors. The teacher in making a learning plan must be able to choose and determine learning approach that is suitable with the material being taught. As instructors, teachers have different teaching styles, but teachers must be able to adapt the learning environment to the conditions of students so that positive interactions occur between teachers and students (Pritchard, 2009). This positive interaction can be achieved one of them by understanding the characteristics of students. This is because each student has different characteristics (Gufron, 2010).

Therefore, in order for the learning process to be effective, a teacher is required to be able to apply a variety of appropriate approaches, because approaches in learning are needed to provide 
opportunities for students in order to obtain an optimal learning experience. In this case Shah (2009) also states that, one of the factors that influence student learning outcomes is the learning approach (approach to learning). The learning approach chosen by a teacher is expected to be a learning approach that allows and emphasizes the process of student involvement to be able to find material and solve problems that are learned independently.

Knowing the learning characteristics of each student in his class is one part of the realm of pedagogical competencies that must be possessed by the teacher. Therefore, before the teacher teaches in class, they should first know the learning characteristics of each student, especially their learning styles.

When the learning process takes place not all students can understand the lesson easily, there are students who easily understand and those who have difficulty when the lesson takes place (Gufron, 2010). One of the causes of this is because there are differences in learning styles possessed by each student. Learning style is the tendency of students to adapt certain strategies in their learning as a form of responsibility to get a learning approach that is appropriate to the demands of learning in class / school and the demands of the subject (Slameto, 2003).

The approach used by the teacher in the learning process needs to pay attention to the overall accommodation of the principles of teaching and learning activities. One of the principles of teaching and learning activities is student-centered. The teacher must view students as something unique, no two students are alike even twins. Students differ in their interests, motivations, volition, pleasures, experiences, and ways of learning. A big mistake if the teacher treats students equally. Learning style (learning style) of students concerned, both visually, auditory, and kinetic (Ira Rahmawati, 2013)

Learning styles can determine a child's learning achievement. If given a strategic approach that suits their learning style, children can develop better. Automatic learning styles depend on people learning. This means that everyone has a different learning style (Ira Rahmawati).

There are many differences in learning styles, the three most popular learning styles that students use in retrieving information are visual, auditory, and kinesthetic learning styles (Gilakjani, 2012). Visual learning style is the tendency of students to rely on the important role of vision in the learning process. Auditory learning style is the tendency of students to rely on the important role of hearing in the learning process. Kinesthetic learning style is the tendency of students to rely on the important role of movement and touch in the learning process (Pritchard, 2009 \& De Porter, 1992).

The approach can be used to improve the results of mathematical reasoning abilities in learning, especially on Mathematics is a RME and Scientific approach. Where learning with RME and scientific approaches is designed so that students actively construct, concepts, laws or principles through the stages of observing, formulating problems, proposing or formulating hypotheses, collecting data with various techniques, analyzing data, drawing conclusions and communicating concepts, a law or principle that is "discovered". 
According to Gravemeijer (1994) realistic mathematics education is rooted in Freudenthal's interpretation of mathematics as an activity" This statement means that RME is based on Freudenthal's view that mathematics is a human activity. Lebih lanjut Ebner (2015) $\mathrm{RME}$ is an approach to mathematics education that involves students developing their understanding by exploring and solving problem set in contexts that engage their interest.

Hadi (2005) describes the learning process in RME, namely: (1) the starting point of learning must provide real experience for students so that they can be directly involved in mathematical activities (2) to accommodate students' mathematical knowledge, the starting point is also must be explained based on the potential goals of the learning sequence; (3) the sequence of learning must involve activities where students create and describe symbolic models of their informal mathematical activities (4) all three teachings are effective if realized in interactive learning (5) the real phenomena of mathematical forms and concepts are manifested in intertwining various sub topics.

Another alternative learning method that can improve students' mathematics learning achievement, mathematical reasoning abilities, and student interest in learning is the scientific approach. The scientific approach makes learning more active and not boring. Students can construct their knowledge and skills through facts found in the field of inquiry for learning.

The scientific approach according to Faisal (2014), is an approach used in learning by focusing on the use of scientific methods in the learning process. Then, according to Daryanto (2014), the learning process in the 2013 curriculum for all levels is carried out using a scientific (scientific) approach. The steps of a scientific approach (scientific appoach) in the learning process include digging information through observation, asking questions, experimenting, then processing data or information, presenting data or information, followed by analyzing, reasoning, then concluding, and creating.

In mathematics learning, for example, students can be invited to see events directly, observe events, phenomena, contexts or situations related to the use of building space, such as cubes as objects that exist in everyday life.

The scientific approach is very relevant to three learning theories namely Bruner's theory, Piaget's theory, and Vygotsky's theory. Bruner's learning theory is also called the theory of discovery learning. There are four main points relating to Bruner's learning theory (Carin $\&$ Sund, 1975). First, the individual only learns and develops his mind when he uses his mind. Second, by carrying out cognitive processes in the process of discovery, students will get a sensation and intellectual satisfaction which is an intrinsic appreciation. Third, the only way that a person can learn techniques for making discoveries is that he has the opportunity to make discoveries. Fourth, by making discoveries it will strengthen memory retention. The four things above are in accordance with the cognitive processes needed in learning using scientific methods. Piaget's Theory, states that learning is related to the formation and development of schemes (plural schemata). Schema is a mental structure or cognitive structure through which a person intellectually adapts and 
coordinates the surrounding environment (Baldwin, 1967).

Some experts express opinions to define a scientific approach. Scientific method according to D'AAico \& Gallaway (2010) has several stages, namely (1) stating the problem; (2). gathering information (3). Developing hypotheses (hypotheses are interpretations of information collected by scientists) (4). Conducting experiments to test the accuracy of hypotheses; (5). record and analyze data collected; (6). States a conclusion.

This study aims to describe the effect of realistic learning approaches, scientific approaches and learning styles on mathematical reasoning abilities.

\section{METHODS}

a. Population and Sample

As the population are students of class X SMK Wahidin Cirebon which is divided into 10 classes with a total population of 335 people. Of the 10 classes of sampling techniques used were random sampling techniques by taking randomly so that obtained class X AP 1 amounted to 35 people as experimental class I using the RME approach and X PM 2 amounted to 35 people as Experiment II class using scientific approach. In the next stage, each group (experimental groups I and II) was divided into two groups, namely groups of students who have visual learning styles and groups of students who have kinesthetic learning styles

\section{b. Research Design}

This research is a quasiexperimental study, where experiments are carried out in existing study groups (classes). It is not possible for researchers to change the class structure that already exists and it is impossible to control all the variables that arise and the conditions of the experiment strictly. (Sugiyono, 2012). 2 $\times 2$ factorial groups which aremerupakan modifikasi dari Pretest-Posttest.

Table 1. 2 x 2 Factorial Analysis Design

\begin{tabular}{lcc}
\hline \multicolumn{1}{c}{ Learning } & \multicolumn{2}{c}{ Approach (A) } \\
\cline { 2 - 3 } style (B) & $\mathrm{A}_{1}$ (RME) & $\mathrm{A}_{2}$ (Scientific) \\
\hline $\mathrm{B}_{1}$ Visual & $\mathrm{A} 1 \mathrm{~B} 1$ & $\mathrm{~A} 2 \mathrm{~B} 1$ \\
$\mathrm{~B}_{2}$ Kinesthetic & $\mathrm{A} 1 \mathrm{~B} 2$ & $\mathrm{~A} 2 \mathrm{~B} 2$ \\
\hline
\end{tabular}

Control Group Design (Fraenkel and Wallen, 2011). In this study there are two independent variables namely the learning approach and learning style, where the approach is divided into the RME approach and the scientific approach. Learning styles are divided into visual learning styles and kinesthetic learning styles. One dependent variable is mathematical reasoning ability.

c. Data Processing Flowchart

Data collection techniques in this study were tests and questionnaires in the form of an initial test (pretest) and a final test (posttest). While the research instruments used in this study are instruments of mathematical reasoning ability tests, and filling learning style questionnaires.

Data analysis uses descriptive statistical analysis and inferential statistical analysis. Descriptive statistical analysis includes the mean (median), median, standard deviation, highest score, and lowest score. In terms of content validity, test instruments and questionnaires are appropriate according to the expert. In terms of construct validity, based on the results of the factor analysis on the student's learning style questionnaire the instrument was declared valid. Reliability tests of mathematical reasoning abilities are 0.743 and 0.721 with SEM of 7.6 and 7.642. The learning 
style questionnaire reliability was 0.863 with a SEM of 5.173.

For inferential analysis includes the first, a prerequisite test that is a normality test using the KolmogorovSmirnov Test, homogeneity test using the Levene's Test. Second, hypothesis testing uses 2-way ANAVA (Analysis of variance). Data analysis was processed with the help of the SPSS 20 program.

\section{RESULT AND DISCUSSION}

The data obtained in this study is the mathematical reasoning ability of students. The results of data normality testing with the Kolmogorov Smirnov Test analysis obtained significance values $(\alpha)=$ 0.45 . This shows that the research data is normally distributed, because the value of $a>0.05$. Homogeneity test results using
Levene's Test obtained a value from the analysis is 0.672 , because the significance ( $\rho$ ) obtained is greater than $\alpha=0.05$, the data is homogeneous.

The effect of learning approaches and learning styles on students' mathematical reasoning ability operationally can be known through differences in mathematical reasoning abilities of each treatment group. The difference in students' mathematical reasoning abilities in each treatment as a result of the manipulation of the independent variables (learning approaches and learning styles) shows that the independent variables affect the dependent variable. The results of testing hypotheses I, II and III in detail are presented in table 4.

Tabel 2. Inferential Statistics Testing Results

Tests of Between-Subjects Effects

\begin{tabular}{|c|c|c|c|c|c|}
\hline Source & $\begin{array}{c}\text { Type III Sum } \\
\text { of Squares }\end{array}$ & $\mathrm{df}$ & $\begin{array}{l}\text { Mean } \\
\text { Square }\end{array}$ & $\mathrm{F}$ & Sig. \\
\hline Corrected Model & $836.006^{\mathrm{a}}$ & 3 & 278.669 & 2.539 & .064 \\
\hline Intercept & 371500.095 & 1 & 371500.095 & $3.385 \mathrm{E} 3$ & .000 \\
\hline Pendekatan & 675.912 & 1 & 675.912 & 6.159 & .016 \\
\hline Gaya_Belajar & 44.380 & 1 & 44.380 & .404 & .527 \\
\hline $\begin{array}{l}\text { Pendekatan * } \\
\text { Gaya_Betajar }\end{array}$ & 100.197 & 1 & 100.197 & .913 & .343 \\
\hline Error & 7242.565 & 66 & 109.736 & & \\
\hline Total & 379650.000 & 70 & & & \\
\hline Corrected Total & 8078.571 & 69 & & & \\
\hline
\end{tabular}

Based on Table 2 shows the test results between research subjects. Data analysis from table 2 includes 2 types: the average difference test based on different variables (learning approaches and learning styles) and the interaction test between categorical variables.

For the average difference test based on the learning method (learning approach) we make a hypothesis: 
$\mathrm{H} 0=\quad$ There is no difference in the influence of the average mathematical reasoning ability of the RME approach and the scientific approach.

$\mathrm{H} 1=$ There is a difference in the average effect of the average mathematical reasoning ability of the RME approach and the scientific approach.

Based on the output of table 2 the probability is 0,000 . Because $0,000<0.05$ then $\mathrm{Ho}$ is rejected. Thus, by using a significance level of 0.05 , it can be concluded that there is an average difference in the average mathematical reasoning ability of the RME approach and the scientific approach

For the average difference test based on student learning styles we make a hypothesis:

$\mathrm{HO}=\quad$ There is no difference in the average effect of mathematical reasoning abilities from visual learning styles and kinesthetic learning styles.

$\mathrm{H} 1=$ There is a difference in the average effect of the average mathematical reasoning ability of the visual learning style and the kinesthetic learning style.

Based on the output of table 2 the probability is 0.963 . Because $0.016<0.05$ then Ho is rejected. Thus, by using a significance level of 0.05 , it can be concluded that there is a difference in the influence of the average mathematical reasoning ability of the visual learning style and the kinesthetic learning style.

For interaction probabilities use the probabilities in the Approach * Learn_style. Obtained a probability of 0.343 , then by using a significance level of 0.05 , it can be concluded that there is no interaction between the learning approach and learning style variables. It can be seen from the results of the overall analysis that the influence of learning approach variables and learning styles on students' mathematical reasoning abilities is $30.3 \%$

\section{CONCLUSION AND IMPLICATION}

\section{a. Conclusion}

The conclusion that can be drawn from the results of research and discussion is that there are differences in the influence of the RME and scientific learning approaches on students' mathematical reasoning abilities in class X SMK Wahidin Cirebon. There is a difference in the influence of kinesthetic learning styles, and visual on the mathematical reasoning ability of students in class X SMK Wahidin Cirebon, there is no interaction between the learning approach and learning style variables..

\section{b. Implication}

It is recommended for teachers, in an effort to master mathematical reasoning, the experimental learning approach is a fairly effective method for mastering the cognitive, affective and psychomotor aspects of students. And the teacher can master the learning approach to be taught so that students become interested in learning mathematics.

Further research should be conducted, this study only revealed a small number of problems related to mathematical mathematical reasoning. The research findings show there are still many factors that influence mathematical reasoning that are not revealed in this study. These factors usually come from within students such as intelligence, interest in learning, and student achievement motivation towards mathematics. And from outside students themselves such as the use of instructional media, teacher professionalism, and so forth. 


\section{ACKNOWLEDGMENTS}

Thanks to the Mathematics teacher and the principal of Wahidin Vocational School who gave me the opportunity to do research, I am very grateful to the students of class X of Wahidin Cirebon Vocational School who have helped the learning process and data collection for this articel in a limited period of time.

\section{REFERENCES}

Baldwin, A. L. (1904). Theories of child development. New Jersey: Wiley.

Carin, A. A., \& Sund, R. B. (1970). Teaching science through discovery. Indiana: $C E$ Merrill Publishing Company.

Ebner, M. (2015). Mobile Learning and Mathematics. Foundations, Design, and Case Studies. London: Routledge

D'Amico, J., \& Gallaway, K. (2010). Differentiated instruction for the middle school science teacher: Activities and strategies for an inclusive classroom (Vol. 3). John Wiley and Sons.

Faisal, M. P. Sukses Mengawal Kurikulum $2013 D i \quad S D$. Yogyakarta: Diandra Creative

Fraenkel, J. R., Wallen, N. E., \& Hyun, H. H. (2011). How to design and evaluate research in education. New York: McGraw-Hill Humanities/Social Sciences/Languages.

Gilakjani, A. P. (2012). Visual, auditory, kinaesthetic learning styles and their impacts on English language teaching. Journal of studies in education, 2(1), 104113.

Ghufron, M. N., \& Risnawita, R. (2012). Gaya Belajar kajian teoritik. Yogyakarta: Pustaka Pelajar.
Gunhan, B. C. (2014). A case study on the investigation of reasoning skills in geometry. South African Journal of Education, 34(2), 1-19

Gravemeijer, K. P. (1994). Developing realistic Mathematics Education (Ontwikkelen van realistisch reken/wiskundeonderwijs).

Hadi, S. (2005). Pendidikan Realistik dan Implementasinya.

Pritchard, A. (2009). Ways of learning: learning theories and learning styles in the classroom. UK: David Fulton Publish.

Rahmawati, I. T. Pengaruh Gaya Belajar Bahasa Terhadap Prestasi Belajar Bahasa Arab Kelas VII Semester II di MTsN Galur. Skripsi Sarjana Pendidikan Bahasa Arab Fakultas Tarbiyah dan Keguruan Universitas Islam Negeri Sunan Kalijaga

Rizqi, N. R., \& Surya, E. (2017). An Analysis Of Students' Mathematical Reasoning Ability In VIII Grade Of Sabilina Tembung Junior High School. International Journal Of Advance Research And Innovative Ideas In Education (IJARIIE), 3(2), 2395-4396

Slameto, (2003). Belajar dan Faktor-faktor yang Mempengaruhinya. Jakarta: Rineka Cipta.

Sugiyono. 2012. Metode Penelitian Pendidikan Pendekatan Kuantitatif, Kualitatif, dan $R \& D$. Bandung: Alfabeta.

Syah, Muhibbin (2009). Psikologi Pendidikan Suatu Pendekatan Baru. Bandung: Remaja Rosdakarya

Making, S. (2009). Focus in high school mathematics: Reasoning and sense making.

Tipps, S., Johnson, A., \& Kennedy, L. M. (2011). Guiding children's learning of mathematics. San Francisco Cengage Learning. 